Jurnal Ilmu Dan Teknologi Kesehatan

Vol X, No X, September 2018,

ISSN: 2338-9095 (Print)

ISSN: 2338-9109 (online)

\title{
Edukasi Gizi dengan CAMIL Sama Efektif dengan Leaflet dalam Prilaku Pencegahan Anemia pada Ibu Hamil
}

\author{
Rista Elmika $^{1}$, Demsa Simbolon ${ }^{2}$, Emy Yuliantini $^{3}$ \\ Poltekkes Kemenkes Bengkulu \\ ristaelmika96@gmail.com
}

\begin{abstract}
Artikel history
Dikirim, Jun $22^{\text {th }}, 2018$

Ditinjau, Aug 20 ${ }^{\text {th }}, 2018$

Diterima, Aug $26^{\text {th }}, 2018$
\end{abstract}

\begin{abstract}
Iron nutritional anemia is anemia caused by iron deficiency in the blood, meaning the concentration of hemoglobin in the blood is less than $11 \mathrm{gr} / \mathrm{dl}$. According to WHO, the incidence of pregnancy anemia ranges between $20 \%$ and $89 \%$ by setting $\mathrm{Hb} 11 \mathrm{~g} \%(\mathrm{~g} / \mathrm{dl})$. The pregnancy anemia rate occurred $3.8 \%$ in the first trimester, $13.6 \%$ trimester II, and $24.8 \%$ in the third trimester. To know the effectiveness of CAMIL media (iron anemia disc pregnant mother) to behavior of prevention of iron anemia in pregnant mother in work area of Beringin Raya Public Health Center of Bengkulu City. This type of research uses Quasy Experimental Study with Pretest-Postest Control Group Design. The population in this study were pregnant women listed in the Register of Beringin Raya Public Health Center of Bengkulu Year 2018. total samples were 40 respondents.20 respondents of the intervention group and 20 control groups. Data analysis using T-test. The result of the research is the effect of CAMIL on knowledge, attitude and action where the sign value $0.000<0.05$. While the Leaflet of behavior (knowledge, attitude, and action) there is influence where the sign value is $0.000<0.05$. There is no difference of knowledge on CAMIL group and leaflet where sign value is 0.106>0.05. For attitudes on the CAMIL group and the leaflet is the same where the sign value is $0.146>0.05$. Action on the CAMIL group and the same leaflet where the sign value is 0.064>0.05. Conclusion From the results of this study it can be concluded that health education is important to improve knowledge, attitude, and action, using CAMIL media and leaflets, both media are equally efketif because it is written with the added pictures
\end{abstract}

Keywords: Iron anemia pregnancy, nutrition education, behavior, pregnant

\begin{abstract}
ABSTRAK
Anemia gizi besi adalah anemia yang terjadi akibat kekurangan zat besi dalam darah, artinya konsentrasi hemoglobin dalam darah kurang dibawah $11 \mathrm{gr} / \mathrm{dl}$. Menurut WHO, kejadian anemia kehamilan berkisar antara 20\% dan 89\% dengan menetapkan $\mathrm{Hb} 11 \mathrm{~g} \%$ (g/dl). Angka anemia kehamilan terjadi 3,8\% pada trimester I, 13,6\% trimester II, dan $24,8 \%$ pada trimester III. Untuk mengetahui efektivitas media CAMIL (Cakram anemia besi ibu hamil) terhadap
\end{abstract}


prilaku pencegahan anemia besi pada ibu hamil di wilayah kerja Puskesmas Beringin Raya Kota Bengkulu. Jenis penelitian ini menggunakan Quasy Experimental Study dengan PretestPostest Control Group Design. Populasi dalam penelitian ini adalah ibu hamil yang tercatat di Register Puskesmas Beringin Raya kota Bengkulu Tahun 2018. total sampel 40 responden.20 responden kelompok intervensi dan 20 kelompok kontrol. Analisis data menggunakan T-test. Hasil penelitian ada pengaruh CAMIL terhadap pengetahuan, sikap dan tindakan dimana didapatkan nilai sign $0.000<0.05$. Sedangkan Leaflet terhadap perilaku (pengetahuan, sikap, dan tindakan) ada pengaruh dimana nilai sign $0.000<0.05$. Tidak ada perbedaan pengetahuan pada kelompok CAMIL dan leaflet dimana nilai sign $0.106>0.05$. Untuk sikap pada kelompok CAMIL dan leaflet itu sama dimana nilai sign $0.146>0.05$. Tindakan pada kelompok CAMIL dan leaflet sama dimana nilai sign $0.064>0.05$. Kesimpulan Dari hasil penelitian ini dapat disimpulkan bahwa pendidikan kesehatan itu penting untuk meningkatkan pengetahuan, sikap, dan tindakan, menggunakan media CAMIL dan leaflet, kedua media ini sama-sama efketif karena merupakan tulisan yang ditambah dengan gambar-gambar

Kata kunci: Anemia besi kehamilan, pendidikan gizi, perilaku, ibu hamil

\section{PENDAHULUAN}

Anemia gizi besi adalah anemia yang terjadi akibat kekurangan zat besi dalam darah, artinya konsentrasi hemoglobin dalam darah kurang dibawah 11 gr\% pada trimester 1 dan 3 atau kadar $<10,5$ gr\% pada trimester 2 karena terganggunya pembentukan sel-sel darah merah akibat kurangnya kadar besi dalam darah. Semakin berat kekurangan zat besi yang terjadi akan semakin berat pula anemia yang diderita (Gibney et al., 2008). Berdasarkan pengertian tersebut diatas dapat diambil kesimpulan bahwa anemia kehamilan merupakan kadar hemoglobin dibawah 11 gr\% pada trimester 1 dan 3 atau kadar $<10,5$ gr\% pada trimester 2 .

Angka anemia kehamilan terjadi 3,8\% pada trimester I, 13,6\% trimester II, dan 24,8\% pada trimester III (Manuaba, 2012).
Data dari Direktorat Kesehatan Keluarga menunjukkan bahwa $40 \%$ penyebab kematian pada ibu hamil adalah perdarahan, risiko perdarahans ini akan lebih diperberat apabila ibu hamil menderita anemia (Depkes RI. 2003). Berdasarkan Laporan hasil Riset KEsehatan Dasar tahun 2013 terdapat $37,1 \%$ ibu hamil anemia yaitu ibu hamil dengan kadar $\mathrm{Hb}$ kurang dari 11,0 gr/dl dengan proporsi yang hampir sama antara di kawasan perkotaan $(36,4 \%)$ dan pedesaan (37,8\%). Tingginya kejadian anemia ini erat kaitannya dengan faktor kurang asupan makanan bergizi saat ibu hamil dan kurangnya kesadaran dalam mengkonsumsi tablet zat besi (Kemenkes, 2013).

Prevalensi yang di dapat dari Dinkes Kota Bengkulu pada tahun 2016 cakupan 
anemia pada ibu hamil sebesar $15,7 \%$. Berdasarkan data perbandingan di Puskesmas Beringin Raya dapat dilihat pada tahun 2015 dengan jumlah ibu hamil 486 yang menderita anemia 13 orang sedangkan pada tahun 2016 jumlah ibu hamil 489 yang menderita anemia meningkat 200 orang. Jumlah kunjungan ibu hamil di puskesmas Beringin raya bulan januari-febuari 2018 sebanyak 47 orang yang nilai $\mathrm{Hb} \leq 11 \mathrm{mg} / \mathrm{dl}$ yaitu 10 orang (Dinkes Kota Bengkulu, 2016). Di Puskesmas Beringin Raya aksesnya mudah dijangkau dan juga merupakan puskesmas perawatan, selain itu kegiatan kelas ibu hamil belum dijalankan dengan baik (Puskesmas Beringin Raya, 2016).

Kebutuhan zat besi pada saat kehamilan meningkat.Beberapa literatur mengatakan kebutuhan zat besi meningkat dua kali lipat dari kebutuhan sebelum hamil.Hal ini terjadi karena selama hamil, volume darah meningkat $50 \%$, sehingga perlu lebih banyak zat besi untuk membentuk hemoglobin. Selain itu, pertumbuhan janin dan plasenta yang sangat pesat juga memerlukan banyak zat besi.Tetapi dalam keadaan hamil, suplai zat besi dari makanan masih belum mencukupi sehingga dibutuhkan suplemen berupa tablet besi (Depkes RI, 2009).
Pengetahuan merupakan salah satu faktor yang menstimulasi atau merangsang terhadap terwujudnya sebuah perilaku kesehatan. Apabila ibu hamil mengetahui dan memahami akibat anemia dan cara mencegah anemia maka akan mempunyai perilaku kesehatan yang baik. Perilaku kesehatan yang demikian berpengaruh terhadap penurunan kejadian anemia pada ibu hamil (Purbadewi, 2013).

Hasil penelitian Sulistiyanti (2015) di Sragen menunjukkan ada hubungan antara variabel pengetahuan dan kepatuhan ibu hamil dalam mengkonsumsi tablet $\mathrm{Fe}$, semakin besar nilai variabel pengetahuan maka semakin besar nilai variable kepatuhan. Menurut penelitiian yang dilakukan Meidayati (2017) ada pengaruh penyuluhan kesehatan tentang pencegahan anemia terhadap sikap dalam pencegahan anemia pada remaja putri di SMA Negeri 1 Yogyakarta. Penelitian Rahmi (2016) juga menunjukan bahwa tidak ada perbedaan pengetahuan setelah diberikan media booklet. Berdasarkan uraian diatas peneliti tertarik untuk mengetahui tentangefektivitas media CAMIL (Cakram anemia besi ibu hamil) terhadap prilaku ibu hamil dalam pencegahan anemia besi di wilayah kerja Puskesmas Beringin Raya Kota Bengkulu. 
METODE PENELITIAN

Penelitian ini menggunakan metode quasy experimental study dengan pretest-post test control group design. Penelitian dilakukan di wilayah kerja Puskesmas Beringin Raya Kota Bengkulu. Populasi dalam penelitian ini adalah ibu hamil yang tercatat di register Puskesmas Beringin Raya Kota Bengkulu tahun 2018. Total sample dalam penelitian ini totalnya adalah 40 responden. 20 responden kelompok intervensi dan 20 kelompok Kontrol. Pengumpulan data primer diperoleh melalui pre-test dan post-test menggunakan kuesioner. Kuesioner pretest dan post-test untuk mengukur pengetahuan, sikap, dan tindakan.. Sedangkan data skunder diperoleh dari data kunjungan ibu hamil di wilayah kerja Puskemas Beringin Raya Kota Bengkulu. Analisis data dilakukan analisis univariat dan bivariat. Analisis univariat digunakan untuk melihat gambaran frekuensi distribusi karakteristik responden, tingkat pengetahuan, sikap dan tindakan. Adapun variabel perancu meliputi usia ibu, usia kehamilan, pendidikan, pekerjaan. Sedangkan Data bivariat menggunakan dua uji yaitu t-test dependen dan t-test independent.

HASIL DAN PEMBAHASAN

Tabel 1. Evaluasi media CAMIL

\begin{tabular}{llccc}
\hline \multirow{2}{*}{ No } & Pernyataan & \multicolumn{3}{c}{ Skor (n=20) } \\
\cline { 3 - 5 } & & Baik(\%) & $\begin{array}{c}\text { Cukup } \\
\mathbf{( \% )}\end{array}$ & Kurang (\%) \\
\hline 1 & Kata-kata sudah jelas & 85 & 15 & 0 \\
\hline 2 & Keruntunan tulisan materi & 65 & 35 & 0 \\
\hline 3 & Bahasa sederhana dan mudah dipahami & 80 & 20 & 0 \\
\hline 4 & Ukuran huruf dan tulisan & 85 & 15 & 0 \\
\hline 5 & Kombinasi warna & 20 & 70 & 10 \\
\hline 6 & Isi materi sesuai dengan pembahasan & 65 & 35 & 0 \\
\hline 7 & Tampilan tulisan dan gambar sudah sesuai & 55 & 40 & 5 \\
\hline
\end{tabular}

Tabel 1 menunjukkan bahwa media edukasi yang dikembangkan berupa CAMIL (Cakram Anemia Besi Ibu Hamil) Model pengembangan yang digunakan dalam penelitian ini yaitu model penelitian dan pengembangan (Research \& Development) yang dikemukakan oleh Lee
\& Owens (2004). Evaluasi media CAMIL dari 20 responden didapatkan hasil katakata sudah jelas $85 \%$ baik dan $15 \%$ cukup, keruntunan tulisan $65 \%$ baik dan $35 \%$ cukup, bahasa sederhana dan mudah dipahami $80 \%$ baik dan $20 \%$ cukup, ukuran huruf dan tulisan $85 \%$ baik dan 
$15 \%$ baik, kombinasi warna $20 \%$ baik, $70 \%$ cukup dan $10 \%$ kurang, isi materi sesuai dengan pembahasan $65 \%$ baik, $35 \%$. Hal ini sejalan dengan penelitian tentang pengembangan multimedia interaktif IPA berorientasi guided inquiry pada materi sistem pernapasan manusia kelas V SDN Kebonsari 3 Malang yang menggunakan model pengembangan lee and owen menunjukan bahwa multimedia interaktif ini termasuk dalam kualifikasi layak untuk digunakan dalam pembelajaran (Akbar, 2016).

Tabel 2 Karakteristik Responden

\begin{tabular}{|c|c|c|c|c|c|}
\hline \multirow{2}{*}{ Karakteristik } & \multicolumn{2}{|c|}{ Cakram } & \multicolumn{2}{|c|}{ Leaflet } & \multirow{2}{*}{ p-value } \\
\hline & $\mathrm{n}=\mathbf{2 0}$ & $\%$ & $\mathbf{n}=\mathbf{2 0}$ & $\%$ & \\
\hline \multicolumn{6}{|l|}{ Umur } \\
\hline$<20$ & 1 & 5 & 4 & 20 & 0,352 \\
\hline $20-35$ & 15 & 75 & 13 & 65 & \\
\hline$>35$ & 4 & 20 & 3 & 15 & \\
\hline \multicolumn{6}{|l|}{ Pendidikan } \\
\hline PT & 2 & 10 & 4 & 20 & 0,635 \\
\hline SMA & 12 & 60 & 11 & 55 & \\
\hline SMP & 5 & 25 & 5 & 25 & \\
\hline SD & 1 & 5 & 0 & 0 & \\
\hline \multicolumn{6}{|l|}{ Pekerjaan } \\
\hline Bekerja & 1 & 5 & 4 & 20 & 0,339 \\
\hline Tidak Bekerja & 19 & 95 & 16 & 80 & \\
\hline \multicolumn{6}{|l|}{ Pendapatan } \\
\hline$>1800000$ & 11 & 55 & 13 & 65 & 0,747 \\
\hline$\leq 1800000$ & 9 & 45 & 7 & 35 & \\
\hline \multicolumn{6}{|l|}{ Ibu hamil } \\
\hline Anemia & 4 & 20 & 6 & 30 & 0,305 \\
\hline Tidak anemia & 16 & 80 & 14 & 70 & \\
\hline
\end{tabular}

Tabel 2 menunjukkan bahwa umur responden kelompok cakram dan leaflet yang lebih dominan kisaran umur 2035 tahun yaitu $75 \%$. Pendidikan responden kelompok cakram dan leaflet banyak yang berpendidikan terakhir SMA yaitu 60\% cakram dan 55\% leafet. Untuk pekerjaan kedua kelompok pada ibu hamil banyak yang tidak bekerja atau ibu rumah tangga. Berdasarkan tingkat pendapatan untuk kelompok cakram dan leaflet pada ibu hamil banyak yg berpenghasilan perbulan lebih dari Rp. 1800000. Hasil uji homogenitas diperoleh dari variabel umur, pendidikan, pekerjaan dan pendapatan pada kelompok CAMIL dan kelompok leaflet homogen $(\mathrm{P}>0,05)$.

Hasil penelitian dengan dua kelompok media cakram dan leaflet menunjukan umur ibu hamil bekisaran 20-35 tahun. Semua responden merupakan wanita yang telah memasuki usia produktif, masa 
tersebut ibu-ibu memiliki kematangan rasional dan psikomotor, dimana kematangan rasional tersebut bermanfat ketika ibu mendapatkan pendidikan kesehatan tentang pencegahan anemia. Maka mereka akan segera memahami tentang anemia besi pada kehamilan. Notoatmodjo (2007) mengemukakan bahwa umur mempunyai pengaruh terhadap daya tangkap dan pola pikir seseorang. Semakin bertambah usia akan semakin berkembang pula daya tangkap dan pola pikirnya.

Distribusi reponden menurut pekerjaan menunjukan sebagian besar ibu rumah tangga atau tidak bekerja. Didapatkan rata- rata pengetahuan sebelum diberikan media leaflet yaitu 57 dengan nilai minimum 50 dan nilai maximum 70. Rata-rata tindakan setelah diberikan media leaflet yaitu 72 , dengan nilai minimum 50 dan maxsimum 100 sehingga didapatkan $p$ value yaitu $0,001(\mathrm{P}<0,05)$ yang menunjukan adanya pengaruh pendidikan kesehatan dengan media leaflet. Nilai rata-rata selisih pengetahuan yang diberikan media leaflet yaitu sebesar 15. Pekerjaan responden berpengaruh terhadap tingkat pengetahuan, karena seseorang yang bekerja diluar rumah cenderung memiliki akses yang baik terhadap informai dibandingkan seseorang yang sehari-hari berada dirumah (Arikunto, 2006).

Tabel 3 Perubahan pengetahuan CAMIL dan Leaflet

\begin{tabular}{lcccccc}
\hline \multirow{3}{*}{ Pengetahuan } & \multicolumn{2}{c}{ Sebelum } & \multicolumn{2}{c}{ Sesudah } \\
\cline { 2 - 7 } & $\begin{array}{l}\text { Min- } \\
\text { Max }\end{array}$ & $\bar{X} \pm$ SD & $\begin{array}{l}\text { Min- } \\
\text { Max }\end{array}$ & $\bar{X} \pm$ SD & $\boldsymbol{\Delta} \bar{X} \pm$ SD & $\begin{array}{c}\boldsymbol{\rho} \\
\text { value* }\end{array}$ \\
\hline CAMIL & $40-80$ & $58 \pm 11,5$ & $50-100$ & $83 \pm 11,3$ & $25 \pm 0,2$ & 0,000 \\
Leaflet & $50-70$ & $57 \pm 7,3$ & $50-100$ & $72 \pm 15,1$ & $15 \pm 7,8$ & 0,001 \\
$\rho$ value** & \multicolumn{2}{c}{0,712} & \multicolumn{2}{c}{0,067} & & \\
\hline
\end{tabular}

$*$ dependent t-test $* *$ independent t-test

Berdasarkan tabel 3 didapatkan rata-rata pengetahuan sebelum diberikan penyuluhan menggunakan media CAMIL yaitu 58 dengan nilai minimum 40 dan nilai maximum 80 . Rata-rata pengetahuan setelah diberikan media CAMIL yaitu 83, dengan nilai minimum 50 dan maxsimum
100 sehingga didapatkan p-value yaitu $0,000(\mathrm{P}<0,05)$ yang menunjukan adanya pengaruh pendidikan kesehatan dengan media CAMIL. Nilai rata-rata selisih pengetahuan yang diberikan media CAMIL yaitu 25 . 
Berdasarkan hasil penelitian yang dilakukan dengan dua kelompok yaitu kelompok intervensi dan kelompok kontrol, didapatkan selisih rata-rata pengetahuan antara media CAMIL dan media leaflet dengan nilai 25 untuk media CAMIL dan 15 untuk media leaflet dimana lebih besar selisih media CAMIL dibandingkan leaflet. Untuk nilai $p$ value menunjukan adanya perubahan pada pengetahuan ibu sebelum (pre) dan sesudah (post), artinya ada pengaruh pengetahuan sebelum dan sesudah diberikan pendidikan gizi. Hal ini dikatakan berpengaruh karena sebelumnya ibu hamil telah mendapatkan penyuluhan mengenai anemia besi ibu hamil di NAKES. Hasil penelitian ini mendukung penelitian menunjukan adanya perubahan pada tingkat penegetahuan ibu sebelum (pre) dan sesudah (post) berarti ada pengaruh pendidikan kesehatan dengan media leaflet dan flipchart tentang anemia pada kehamilan terhadap tingkat pengetahuan ibu hamil di UPT Puskesmas Bukit Hindu Palangka Raya (Sianipar, 2016).

Penelitian lain yang dilakukan tentang efektifitas pendidikan kesehatan dengan menggunakan media leaflet dan media slide power point terhadap perubahan pengetahuan, sikap dan perilaku deteksi dini kanker serviks pada ibuibu PKK di wilayah kerja Puskesmas Kartasura

Sukoharjo. Penelitian tersebut menyimpulkan ada peningkatan pengetahuan setelah menerima leaflet (Khoiron et al., 2014). Pengetahun adalah sebagai suatu pembentukan yang terus menerus oleh seseorang yang setiap saat mengalami reorganisasi karena adanya pemahaman-pemahaman baru (Budiman, 2013). Faktor yang meningkatnya pengetahuan adalah informasi saat dilakukan penyuluhan pada responden dengan metode ceramah dan tanya jawab juga pengunaan media CAMILyang diterima responden. Faktor lain yang mempengaruhi pengetahuan responden salah satunya pengaruh media massa (Budiman dan Riyanto, 2013).

Berdasarkan hasil penelitian menunjukan bahwa tidak ada perbedaan pengetahuan antara kelompok perlakuan (CAMIL) dan kelompok kontrol (leaflet) dimana nilai Pvalue $0,067>0,05$, dari kedua media tersebut yang lebih berpengaruh terhadap pengetahuan yaitu media CAMIL dengan selisih rata-rata sebelum dan sesudah didapatkan 25. Pada hasil sikap menunjukan bahwa nilai P-value 0,115 > 0,05 yang artinya tidak ada perbedaan antara kelompok perlakuan (CAMIL) dengan kelompok kontrol (leaflet), dari kedua media tersebut yang lebih berpengaruh terhadap sikap yaitu media 
CAMIL dengan selisih rata-rata sebelum dan sesudah didapatkan 16,5. Dari hasil uji statistik dapat dikatakan tidak ada perbedaan antara media CAMIL dan media Leaflet dengan nilai P-valiue 0,078 $>0,05$, dari kedua media tersebut yang lebih berpengaruh terhadap pengetahuan yaitu media CAMIL dengan selisih rata- rata sebelum dan sesudah didapatkan 22 . Penelitian ini sejalan dengan penelitian Rahmi (2016) tidak ada perbedaan pengetahuan pada kelompok booklet dimana nilai $\mathrm{P}$-value $0,470>0,05$ dan pada kelompok leaflet dengan nilai $0,142>$ 0,005 .

Tabel 4 Perubahan Sikap dengan CAMIL dan Leaflet

\begin{tabular}{|c|c|c|c|c|c|c|}
\hline \multirow[b]{2}{*}{ Sikap } & \multicolumn{2}{|c|}{ Sebelum } & \multicolumn{2}{|c|}{ Sesudah } & \multirow[b]{2}{*}{$\bar{X} \underset{ \pm \mathbf{S D}}{\stackrel{\Delta}{\mathbf{S}^{2}}}$} & \multirow[b]{2}{*}{$\begin{array}{c}\rho \\
\text { value }\end{array}$} \\
\hline & $\begin{array}{l}\text { Min- } \\
\text { Max }\end{array}$ & $\bar{X} \pm$ SD & $\begin{array}{l}\text { Min- } \\
\text { Max }\end{array}$ & $\bar{X} \pm$ SD & & \\
\hline CAMIL & $40-80$ & $63,5 \pm 9,3$ & $60-90$ & $80 \pm 9,1$ & $16,5 \pm 0,2$ & 0,000 \\
\hline Leaflet & $40-80$ & $63,5 \pm 9,8$ & $60-100$ & $75,5 \pm 9,9$ & $12 \pm 0,1$ & 0,000 \\
\hline$\rho$ value $* *$ & & ,942 & & 115 & & \\
\hline
\end{tabular}

*dependent $\mathrm{t}$-test $* *$ independent $\mathrm{t}$-test

Tabel 4 menunjukkan bahwa rata-rata sikap sebelum diberikan penyuluhahan menggunakan media CAMIL yaitu 63,5 dengan nilai minimum 40 dan nilai maximum 80. Rata-rata sikap setelah diberikan media CAMIL yaitu 80, dengan nilai minimum 60 dan maxsimum 90 sehingga didapatkan $p$-value yaitu 0,000 $(\mathrm{P}<0,05)$ yang menunjukan adanya pengaruh pendidikan kesehatan dengan media CAMIL. Nilai rata-rata selisih sikap yang diberikan CAMIL yaitu 16,5. Didapatkan rata-rata tindakan sebelum diberikan media leaflet yaitu 63,5 dengan nilai minimum 40 dan nilai maximum 80 . Rata-rata sikap setelah diberikan media leaflet yaitu 75,5 , dengan nilai minimum 60 dan maxsimum 100 sehingga didapatkan $\mathrm{P}$-value yaitu $0,000(\mathrm{P}<0,05)$ yang menunjukan adanya pengaruh pendidikan kesehatan dengan media leaflet. Nilai rata-rata selisih sikap yang diberikan media leaflet yaitu sebesar 12 .

Hasil selisih rata-rata sikap pada media CAMIL sebesar 16,5 dan media leflet sebesar 12, ini menunjukan bahwa selisih media CAMIL dibandingkan dengan selisih media leaflet. Pada nilai $p$ value kelompok intervensi dan kelompok kontrol menunjukan bahwa setelah diberikan media CAMIL dan leaflet pada ibu hamil adanya perubahan pada sikap ibu sebelum dan sesudah dengan p-value 0,000 $<0,05$ yang artinya ada pengaruh media edukasi gizi yang diberikan CAMIL dan leaflet terhadap sikap dalam pencegahan anemia 
kehamilan. Tidak ada perbedaan sikap pada kelompok booklet tidak ada perbedaan dimana nilai P-value 0,153 > 0,05 dan pada kelompok leaflet 0,940 > 0,05 . Artinya promosi kesehatan dengan media CAMIL dan Leaflet efektif untuk meningktakan sikap. Hal ini sejalan dengan penelitian Meidayati (2017) menemukan bahwa ada pengaruh penyuluhan kesehatan tentang pencegahan anemia terhadap sikap dalam pencegahan anemia pada remaja putri di SMA Negeri 1 Yogyakarta. Hal ini dikuatkan oleh teori Azwar (2009) menyatakan bahwa faktor yang mempengaruhi pembentukan sikap salah satunya yaitu pengaruh orang lain yang dianggap penting. Orang lain yang dianggap semisal adalah konselor atau penyuluh yang sesuai dengan latar belakang keilmuan (Azwar, 2009). Penelitian yang juga dilakukan menyimpulkan bahwa terdapat pengaruh pendidikan kesehatan terhadap perubahan pengetahuan ibu tentang tablet Fe (Ferum) dan terdapat pengaruh pendidikan kesehatan terhadap perubahan sikap ibu tentang tablet $\mathrm{Fe}$ (Ferum) Di Rumah Bersalin Sri Lumintu Surakarta (Astuti, 2012).

Dari hasil penelitian didapatkan selisih rata-rata tindakan pada media CAMIL sebesar 22 dan untuk media leaflet sebesar 13 menunjukan bahwa selisih rata-rata media CAMIL lebih besar dari pada media leaflet. Pada kelompok CAMIL dan kelompok leaflet didapatkan hasil bahwa adanya perubahan pada tindakan ibu sebelum dan sesudah diberikan pendidikan gizi dengan $\mathrm{p}$-value $0,000<0,05$ yang artinya ada pengaruh setelah diberikan media CAMIL dan leaflet terhadap tindakan dalam pencehagan anemia kehamilan. Hal ini sejalan dengan penelitian Purbowati (2016) menemukan ada pengaruh konseling menggunakan lembar balik dan leaflet terhadap kepatuhan ibu hamil mengkonsumsi tablet besi menunjukkan bahwa ada perbedaan bermakna kepatuhan konsumsi tablet besi setelah diberi perlakuan konseling menggunakan lembar balik dan leaflet antara kelompok perlakuan dengan kelompok kontrol $(p=0,001)$. Penelitian lainnya menyimpulkan bahwa ada pengaruh leaflet dan konseling terhadap kepatuhan minum tablet besi dan kadar hemoglobin ibu hamil dengan anemia di Puskesmas di Kabupaten Bogor (Vernissa et al., 2017).

Berdasarkan table 5 didapatkan rata-rata tindakan sebelum diberikan penyuluhahan menggunakan media CAMIL yaitu 61,5 dengan nilai minimum 50 dan nilai maximum 80. Rata-rata tindakan setelah diberikan media CAMIL yaitu 83,5, dengan nilai minimum 60 dan maxsimum 
100 sehingga didapatkan P-value yaitu $0,000(\mathrm{P}<0,05)$ yang menunjukan adanya pengaruh pendidikan kesehatan dengan media CAMIL.

Tabel 5 Perubahan tindakan dengan diberikan media CAMIL dan media Leaflet

\begin{tabular}{llccccc}
\hline Tindakan & \multicolumn{2}{c}{ Sebelum } & \multicolumn{2}{c}{ Sesudah } \\
& \multicolumn{1}{c}{ Min- } & $\bar{X}^{ \pm} \mathrm{SD}$ & Min-Max & $\bar{X} \pm \mathrm{SD}$ & $\Delta_{\bar{X}}^{ \pm}$ & $\rho$ value* \\
& Max & & & & $\mathrm{SD}$ & \\
\hline CAMIL & $50-80$ & $61,5 \pm 9,3$ & $60-100$ & $83,5 \pm 10,8$ & $22 \pm 1,5$ & 0,000 \\
Leaflet & $50-80$ & $63,5 \pm 8,1$ & $60-100$ & $76,5 \pm 12,2$ & $13 \pm 4,1$ & 0,001 \\
$\rho$ value** & \multicolumn{2}{c}{0,483} & \multicolumn{2}{c}{0,078} & & \\
*dependent t-test **independent t-test & & &
\end{tabular}

Nilai rata-rata selisih tindakan yang diberikan CAMIL yaitu 22. Didapatkan rata-rata tindakan sebelum diberikan media leaflet yaitu 63,5 dengan nilai minimum 50 dan nilai maximum 80. Ratarata tindakan setelah diberikan media leaflet yaitu 76,5 , dengan nilai minimum 60 dan maxsimum 100 sehingga didapatkan $\mathrm{P}$-value yaitu $0,001 \quad(\mathrm{P}<0,05)$ yang menunjukan adanya pengaruh pendidikan kesehatan dengan media leaflet. Nilai rata-rata selisih tindakan yang diberikan media leaflet yaitu sebesar 13 . Hasil penelitian juga menunjukan bahwa pendidikan kesehatan dengan media CAMIL dan Leaflet efektif untuk memperbaiki tindakan ibu hamil. Penelitian sejalan yang dilakuan Purbowati (2016) membutkikan bahwa ada pengaruh konseling menggunakan lembar balik dan leaflet terhadap kepatuhan ibu hamil mengkonsumsi tablet besi, demikian juga temuan Vernissa (2017) membuktikan bahwa baik konseling maupun edukasi dengan leaflet berhubungan dengan kepatuhan minum tablet besi dan kadar hemoglobin ibu hamil dengan anemia di Puskesmas di Kabupaten Bogor.

Rata-rata hasil pengetahuan, sikap dan tindakan ibu hamil pada saat pre test terjadi peningkatan pada saat post test, baik kelompok CAMIL maupun kelompok leaflet tentang pencegahan anemia besi pada kehamilan hal ini terjadi karena setelah diberikan CAMIL dan leaflet adanya minat dari ibu hamil untuk membacanya dan bisa dilakukan berulangulang karena CAMIL dan leaflet merupakan tulisan yang ditambah dengan gambar-gambar. Akan tetapi adapun hambatan yang mempengaruhi jalannya penyuluhan yang diberikan media CAMIL. 
Hambatan yang dialami berupa tempat penelitan, yang mana tempat penelitian sempit dan kurang nyaman mengakibatkan responden kurang memperhatikan dan menyimak materi yang disampaikan menggunakan CAMIL. Dari hasil penelitian ini bahwa pendidikan kesehatan itu penting untuk meningkatkan pengetahuan, sikap, dan tindakan. Dapat memberikan pendidikan kesehatan, penyuluhan secara langsung menggunakan metode diskusi atau media seperti CAMIL, leaflet, booklet, lembar balik, dan lain-lain. Pada penelitian ini menggunakan media CAMIL dan leaflet dimana media CAMIL ini di desain sendiri sedangkan leaflet tidak dibuat sendiri karena sudah ada pembuatan leaflet sebelumnya, kedua media ini sama-sama efketif karena merupakan tulisan yang ditambah dengan gambar-gambar, serta media CAMIL dan leaflet sama-sama praktis.

\section{SIMPULAN}

Edukasi gizi menggunakan media CAMIL efektif untuk meningktakan pengetahuan, sikap dan tindakan ( $p$ value $<0.05)$, demikian juga edukasi dengan Leaflet dapat meningkatkan pengetahuan, dan tindakan ( $\mathrm{p}$ value $<0.05)$, namun peningkatan skor pegetahuan, sikap dan tindakan lebih tinggi menggunakan CAMIL .

\section{DAFTAR RUJUKAN}

Akbar, Nuril Taufik. 2016. Pengembangan Multimedia Interaktif Ipa Berorientasi Guided Inquiry Pada Materi Sistem Pernapasan Manusia Kelas $V \quad S d n$ Kebonsari 3 Malang. Jurnal Pendidikan, 1 (6): $1120-1126$

Arikunto. 2006. Prosedur Penelitian Suatu Pendekatan Praktek. Jakarta : PT. Rineka Cipta

Astuti, E. 2012. Pengaruh Pendidikan Kesehatan Terhadap Perubahan Pengetahuan Dan Sikap Ibu Hamil Dalam Mengkonsumsi Tablet Fe (Ferum) Di Rumah Bersalin Sri Lumintu Surakarta

Azwar, S. 2009. Sikap Manusia Teori dan Pengukurannya. Yogyakarta : Pustak Pelajar

Budiman \& Riyanto A. 2013. Kapita Selekta Kuisioner Pengetahuan Dan Sikap Dalam Penelitian Kesehatan. Jakarta : Salemba Medika: 66-69.

Depkes RI, 2009. Suplementasi Gizi. Direktorat Jendral Bina Kesehatan Masyarakat. Direktorat Bina Gizi Masyarakat

Depkes RI. 2003. Pogram Penanggulangan Anemia Gizi pada Wanita Usia Subur (WUS). Jakarta. Diakses : 29 Maret 2011.

Gibney MJ, Margets MB, Kearney JM, Arab L. 2008. Gizi Kesehatan Masyarakat. Jakarta : EGC

Kemenkes RI. 2013. Riset Kesehatan Dasar; RISKESDAS. Jakarta: Balitbang Kemenkes Ri

Khoiron, N. Sulastri, dan Suryandari, D. 2014. Efektifitas Pendidikan Kesehatan Dengan 
Menggunakan Media Leaflet Dan

Media Slide Power Point Terhadap Perubahan

Pengetahuan,Sikap, Dan Perilaku Deteksi Dini Kanker Srviks Pada Ibu PKK Di Wilayah Kerja Puskesmas Kartasura Sukoharjo Tahun 2014. Universitas Muhammadiyah Surakarta

Manuaba, I.B.G. 2012. Ilmu Kebidanan, Penyakit Kandungan Dan Keluarga Berencana Untuk Pendidikan Bidan. Jakarta: ECG

Meidayati, R. 2017. Pengaruh Penyuluhan Kesehatan Tentang Pencegahan Anemia Terhadap Sikap Dalam Pencegahan Anemia Pada Remaja Putri Di Sma Negeri 1 Yogyakarta. Fakultas Ilmu Kesehatan Universitas 'Aisyiyah Yogyakarta

Notoatmodjo, S. 2007. Promosi Kesehatan dan Ilmu Perilaku. Jakarta: Rineke Cipta

Purbadewi, L. Ulvie, S. 2013. Hubungan Tingkat Pengetahuan Tentang Anemia Dengan Kejadian Anemia Pada Ibu Hamil. Jurnal Universitas Muhammadiyah Semarang, 2 (1):

Purbowati Niken. 2016. Pengaruh Konseling Menggunakan Lembar Balik Dan Leaflet Terhadap Kepatuhan Ibu Hamil
Mengkonsumsi Tablet Besi. Poltekkes Kemenkes Jakarta III 4 (3):

Rahmi. 2016. Efektivitas Media Pendidikan Kesehatan Terhadap Pengetahuan Dan Sikap Ibu Hamil Tentang Tablet Tambah Darah Di BPM Jawiriyah Banda Aceh. Jurnal Kesehatan Ilmiah Nasuwakes, 9 (2): 311-318

Sianipar, S. Aziz, Z. Prilia, E. 2016. Pengaruh Pendidikan Kesehatan Tentang Anemia Pada Kehamilan Terhadap Pengetahuan Ibu Hamil Di UPT Puskesmas Bukit Hindu Palangka Raya. Sekolah Tinggi Ilmu Kesehatan Eka Harap Palangka Raya, 7 (1):

Sulistiyanti, Anik. 2015. Hubungan Tingkat Pengetahuan Ibu Hamil Tentang Anemia Dengan Kepatuhan Konsumsi Tablet FE Diwilayah Kerja Puskesmas Masaran 1 Sragen. Jurnal Kebidanan Dan Ilmu Kesehatan, 2 (2):

Vernissa, V. Retnosari, A. Sudibyo, S. 2017. Efektivitas Leaflet dan Konseling terhadap Kepatuhan Minum Tablet Besi dan Kadar Hemoglobin Ibu Hamil dengan Anemia di Puskesmas di Kabupaten Bogor. Media Litbangkes, 27 (4): 229-236 